\title{
Eficiência fotossintética e produtiva de milho safrinha em função de épocas de semeadura e populações de plantas
}

\author{
Anna Luiza Farias dos Santos ${ }^{1}$, Ivan Arcanjo Mechi ${ }^{1}$, Luan Marlon Ribeiro ${ }^{1}$, Gessí Ceccon ${ }^{2}$ \\ ${ }^{1}$ Universidade Federal da Grande Dourados, Dourados, Mato Grosso do Sul, Brasil. E-mail: annaluiza_di@hotmail.com, \\ ivarmec@hotmail.com, luanmarlon@hotmail.com \\ ${ }^{2}$ Empresa Brasileira de Pesquisa Agropecuária - Embrapa Agropecuária Oeste - CPAO, Dourados - MS, Brasil. E-mail: \\ gessi.ceccon@embrapa.br
}

Recebido: 28/04/2017; Aceito: 17/10/2018.

\section{RESUMO}

A pesquisa foi realizada com o objetivo de avaliar os componentes produtivos e variáveis fotossintéticas de plantas de milho cultivadas em quatro épocas de semeadura e quatro populações de plantas. O delineamento experimental foi em blocos casualizados, com parcelas subdivididas e quatro repetições. Nas parcelas foram alocadas as épocas de semeadura do milho safrinha ( 01 e 15 de fevereiro e 01 e 15 de março) e, nas subparcelas, as populações de plantas $\left(50,60,70\right.$ e 80 mil plantas ha $\left.{ }^{-1}\right)$. As maiores taxas fotossintéticas e eficiência de carboxilação da Rubisco foram observadas nas plantas das semeaduras de 15/02 e 15/03. A semeadura realizada em 15/02 e 01/03 resultou na maior massa de 100 grãos e grãos por espiga. Em relação à produtividade de grãos, a única época que diferiu das demais foi a semeadura em 15/02, apresentando a menor média. As maiores médias de grãos por espiga e massa de 100 grãos foram observadas nas plantas da população de 50 mil plantas ha ${ }^{-1}$. As semeaduras realizadas em 15/02 e 15/03 favoreceram os processos fotossintéticos das plantas de milho. A maior produtividade ocorreu com a semeadura em 15/02. Menores populações de milho foram suficientes para garantir a satisfatória produtividade do milho safrinha.

Palavras-chave: densidade populacional, produtividade, taxa fotossintética, Zea mays.

\section{Photosynthetic and productive efficiency of off-season corn in the function of sowing dates and plant populations}

\begin{abstract}
The research was carried out with the objective of evaluating the productive components and photosynthetic variables of corn plants, grown in four sowing dates and four plant populations. The experimental design was in randomized blocks, with plots subdivided into four replicates. In the plots the sowing dates of the corn crop were allocated (01 and 15 of February and 01 and 15 of March) and in the subplots the plant populations (50, 60, 70, and 80 thousand plants $\mathrm{ha}^{-1}$ ). The highest photosynthetic rates and carboxylation efficiency of Rubisco were observed in the sowing plants on Feb. 15 and Mar. 15. The sowing performed on Feb. 15 and March 01 resulted in the largest 100-grain weight and grains per spike. Regarding grain yield, the only time that was different from the others was sowing on Feb. 15, presenting the lowest average. The highest averages of grain per ear and 100-grain weight were observed in the plants of the population of 50 thousand plants ha ${ }^{-1}$. Sowing at Feb. 15 and Mar. 15 favored the photosynthetic processes of corn plants. The highest grain yield occurred with sowing at Feb. 15 . Lower corn plant populations are sufficient to ensure satisfactory corn yields.
\end{abstract}

Keywords: photosynthetic rates, plant densities, productivity, Zea mays. 


\section{Introdução}

A crescente demanda por alimentos leva à necessidade de se produzir cada vez mais, porém, sem expressivo aumento na quantidade de áreas cultivadas. Contudo, a produtividade de grãos é uma variável complexa e depende da interação entre fatores os genéticos e ambientais. As oscilações na produtividade do milho entre os anos estão relacionadas com as variações das condições climáticas, escolha das cultivares, épocas de semeadura e densidade populacional.

Entre os possíveis manejos que podem contribuir para melhores produtividades na cultura do milho safrinha estão o arranjo espacial e a época de semeadura (Kappes et al., 2011). Uma forma de minimizar o efeito dos fatores climáticos é adequar a data de semeadura, principalmente aqueles ligados à disponibilidade hídrica do solo (Sans et al., 2001), que além de interferir na interceptação de radiação solar e absorção de nutrientes, é uma alternativa de escape de temperaturas desfavoráveis e possíveis geadas que coincidam com fases importantes da cultura.

Em relação à população de plantas, a densidade ideal seria aquela que proporciona a melhor distribuição das plantas em determinada área, diminuindo a competição intraespecífica por água, luz e nutrientes. Maiores populações de plantas afetam negativamente alguns componentes de produção, como massa de cem grãos e número de grãos por espiga, porém, podem apresentar maiores produtividades por incrementarem o número de espigas em uma determinada área (Dourado Neto et al., 2003). Todavia, a população pode ser elevada até atingir o número ideal de plantas por hectare; acima disso, a produção de grãos decresce.

Além dos componentes relacionados à produtividade, é necessário conhecer os processos ligados ao crescimento e desenvolvimento das plantas. Dados relacionados ao processo fotossintético são de suma importância para se expor o real desempenho das plantas em determinadas situações. Objetivou-se com essa pesquisa avaliar os componentes produtivos e variáveis fotossintéticas de plantas de milho cultivadas em quatro épocas de semeadura e quatro populações de plantas.

\section{Material e Métodos}

O trabalho foi conduzido na área experimental da Embrapa Agropecuária Oeste, em Dourados, MS ( $22^{\circ} 13^{\prime} \mathrm{S}$ e $\left.54^{\circ} 48^{\prime} \mathrm{W}\right)$. O solo é classificado como Latossolo Vermelho distroférrico, textura muito argilosa (Santos et al., 2013). Com base nos dados do Guia Clima (Embrapa, 2016), o clima da região, segundo a classificação de Köppen, é Tropical Monçônico (Am). Os valores semanais da precipitação pluvial, das temperaturas máximas e mínimas e da radiação solar total diária incidente na superfície do solo foram obtidos na Estação Meteorológica da Embrapa Agropecuária Oeste (Figura 1 e 2).

Foi avaliado o desempenho do híbrido simples DKB 390 VT PRO em delineamento experimental de blocos casualizados, com parcelas subdivididas e quatro repetições. Nas parcelas foram alocadas as épocas de semeadura do milho safrinha, sendo: 01 e 15 de fevereiro e 01 e 15 de março de 2015 e, nas subparcelas, as populações de plantas de milho: 50, 60, 70 e 80 mil plantas ha ${ }^{-1}$.

As unidades experimentais foram compostas por cinco fileiras de $5 \mathrm{~m}$, espaçadas em $0,45 \mathrm{~m}$. O milho foi semeado mecanicamente em uma área de sistema plantio direto, com histórico de sucessão soja-milho safrinha. A população foi de 80 mil plantas ha ${ }^{-1}$ e dez dias após a emergência foi realizado o desbaste manual, ajustando nas populações desejadas. A adubação de semeadura foi de $200 \mathrm{~kg} \mathrm{ha}^{-1}$ da fórmula NPK 08-20-20, sem adubação nitrogenada de cobertura.

Nos primeiros dias do estádio de florescimento das plantas (R1) de cada época de semeadura foram realizadas as medições dos dados fotossintéticos, com auxílio de um analisador de gases no infravermelho (IRGA). Foi avaliada uma planta da terceira linha de cada subparcela, sempre na primeira folha oposta abaixo da espiga, no período de oito a dez horas da manhã em dias ensolarados. As datas em que foram realizadas as avaliações fotossintéticas de cada época de semeadura e as médias de temperatura ambiente no momento da medição estão representadas na tabela 1 .

Foram avaliados temperatura foliar (Tfolha), transpiração (E), concentração interna de $\mathrm{CO}_{2}$ (ci), taxa fotossintética (A), condutância estomática (gs), consumo de $\mathrm{CO}_{2}(\Delta \mathrm{C})$, radiação fotossinteticamente ativa incidente na folha (Qfolha), eficiência de carboxilação da Rubisco (A/ci), eficiência do uso da água - EUA (A/E) e eficiência fotoquímica da fotossíntese (A/Qfolha).

Durante o estádio de florescimento, foram coletadas cinco plantas de milho em todas as subparcelas para avaliações de diâmetro de colmo (DC), rendimento de massa seca de folha (RMSF), de colmo (RMSC) e total (RMST). A massa seca das plantas foi obtida pela secagem em estufa à temperatura de $60{ }^{\circ} \mathrm{C}$ até massa constante. Os rendimentos de massa seca de folha, colmo e total foram estimados com base na população final de milho.

Tabela 1. Datas em que foram realizadas as avaliações fotossintéticas e médias de temperatura ambiente no momento da medição. Dourados, MS, 2017

\begin{tabular}{ccc}
\hline $\begin{array}{c}\text { Época de } \\
\text { semeadura }\end{array}$ & $\begin{array}{c}\text { Datas das } \\
\text { avaliações }\end{array}$ & Temperatura $\left({ }^{\circ} \mathrm{C}\right)$ \\
\hline $01 / 02 / 2015$ & $03 / 04 / 2015$ & 36,2 \\
$15 / 02 / 2015$ & $24 / 04 / 2015$ & 37,7 \\
$01 / 03 / 2015$ & $13 / 05 / 2015$ & 33,2 \\
$15 / 03 / 2015$ & $26 / 05 / 2015$ & 35,8 \\
\hline
\end{tabular}




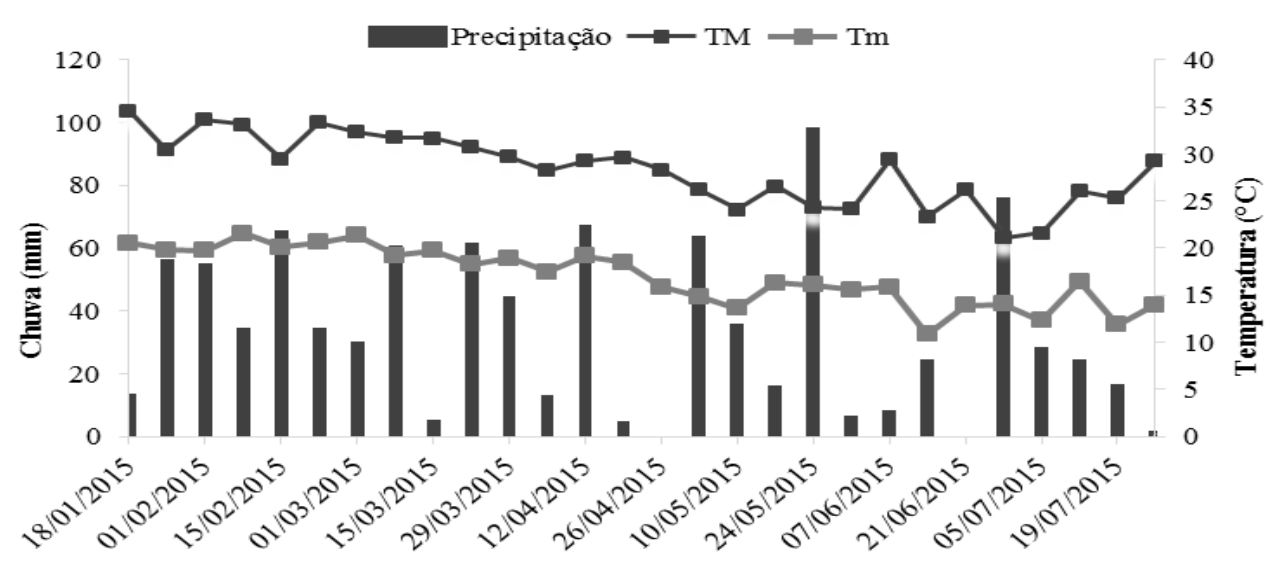

Figura 1. Valores semanais da precipitação pluvial e das temperaturas máximas (TM) e mínimas (Tm) no período de janeiro a julho de 2015, Dourados, MS. Fonte: Embrapa Agropecuária Oeste (2016).

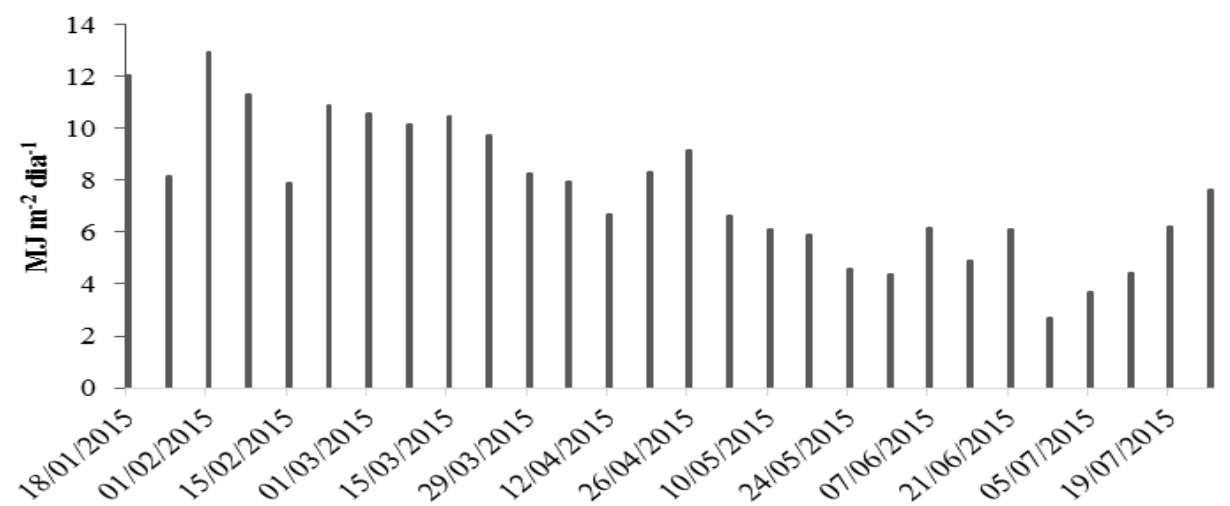

Figura 2. Média semanal da radiação solar total diária incidente na superfície do solo no período de janeiro a julho de 2015 , Dourados, MS. Fonte: Embrapa Agropecuária Oeste (2016).

No estádio de maturação fisiológica, foi avaliada a massa de 100 grãos (M100) e calculado o número de grãos por espiga e produtividade. Para tanto, foram colhidas as espigas e realizada a contagem das plantas presentes nas duas linhas centrais das subparcelas. Posteriormente à colheita, foi realizada a contagem e debulha das espigas, aferição da massa de grãos e contagem de cem grãos para confecção de uma subamostra, a qual foi levada para secagem em estufa à temperatura constante de $60{ }^{\circ} \mathrm{C}$. Ajustou-se, então, a massa de grãos para a umidade de $13 \%$ em base úmida.

Os dados foram submetidos à análise de variância com probabilidade de $5 \%$ de erro e quando encontradas diferenças significativas, as médias de épocas de semeadura e cultivos foram comparadas pelo teste de Tukey $(\mathrm{P}<0,05)$, sendo as médias de população de plantas submetidas à análise de regressão de melhor ajuste por meio do software GENES (Cruz, 2004).

\section{Resultados e Discussão}

A análise de variância apresentou efeito isolado da época de semeadura para temperatura foliar (Tfolha), radiação fotossinteticamente ativa incidente na superfície foliar (Qfolha), condutância estomática (gs), concentração interna de carbono (ci), transpiração (E) e eficiência do uso da água (EUA). Houve influência da interação entre épocas de semeadura e população de plantas para consumo de carbono $(\Delta \mathrm{C})$, taxa fotossintética (A), eficiência de carboxilação da Rubisco (A/ci) e eficiência fotoquímica da fotossíntese (A/Qfolha).

A maior temperatura foliar foi observada nas plantas do tratamento com semeadura em 15/02 e, a menor, nas plantas na semeadura de 01/03 (Tabela 2). As oscilações na temperatura foliar entre as épocas de semeadura coincidiram com as variações da temperatura ambiente observadas no estádio de florescimento de cada época de semeadura (Figura 1 e Tabela 1), com temperaturas elevadas na semana do dia 26/04 e menores valores na semana do dia 10/05.

Oliveira et al. (2005) relacionaram maiores temperaturas foliares à condição de déficit hídrico. Isso justifica a alta temperatura foliar observada nas plantas da semeadura em 15/02, onde houve escassez hídrica na semana em que se realizaram as medições (24/04). O inverso ocorreu com a semeadura em 01/03, com 
precipitação constante no florescimento das plantas e menor temperatura foliar (13/05).

As maiores médias de condutância estomática foram observadas nas plantas das semeaduras em 15/02 e $15 / 03$, sem diferir estatisticamente entre si $(0,383$ e $0,386 \mathrm{~mol} \mathrm{CO}_{2} \mathrm{~m}^{-2} \mathrm{~s}^{-1}$, respectivamente). Na semeadura em 15/02, as plantas receberam maior média de radiação fotossinteticamente ativa incidente na superfície foliar $\left(1.628 \mu \mathrm{mol}\right.$ fótons $\left.\mathrm{m}^{-2} \mathrm{~s}^{-1}\right)$, superando as demais épocas (Tabela 2).

Maiores valores de condutância estomática ocorrem quando a radiação solar é alta e o potencial hídrico da folha ainda não atingiu valores mínimos passíveis de induzir o fechamento estomático (Ferreira et al., 1999; Costa; Marenco, 2007). A elevada radiação fotossinteticamente ativa incidente na superfície foliar das plantas está ligada à alta radiação solar líquida, que foi maior na semeadura em 01 e 15 de fevereiro (Figura 2); consequentemente, justifica a maior condutância estomática nas plantas da semeadura em 15/02. Porém, essa justificativa não se aplica às plantas da semeadura em 15/03, onde a condutância estomática foi alta e a radiação fotossinteticamente ativa incidente na superfície foliar foi inferior à segunda época de semeadura. Nesse caso, outros fatores influenciaram a condutância estomática, como temperatura e teor de água na folha.

A fase fotoquímica da fotossíntese ocorre no fotossistema II e é responsável pela absorção de luz e transporte de elétrons para o fotossistema I, onde se inicia o processo de fotossíntese. Sua eficiência é obtida através da razão entre fotossíntese e radiação fotossinteticamente ativa incidente na superfície foliar (Qfolha). Uma alta eficiência fotoquímica significa que a planta foi eficiente na transformação da energia luminosa em ATP. As plantas da semeadura em 15/02 receberam a maior quantidade de radiação fotossinteticamente ativa na superfície foliar (Tabela 2), porém, não foi eficiente em convertê-la em energia como as plantas da semeadura em 15/03, que receberam menor incidência de radiação fotossinteticamente ativa e apresentaram as maiores médias de eficiência fotoquímica (Figura 4).

A maior média para transpiração foi observada nas plantas da semeadura em 15/02, com média de 7,07 mmol $\mathrm{H}_{2} \mathrm{O} \mathrm{m} \mathrm{m}^{-2} \mathrm{~s}^{-1}$. As plantas das demais épocas de semeadura apresentaram valores iguais estatisticamente (Tabela 3). Segundo Oliveira et al. (2005), a transpiração é um dos métodos que a planta utiliza para manter a temperatura foliar igual ou ligeiramente inferior à temperatura do ar. A transpiração é um reflexo da capacidade de refrigeração das plantas, por isso a alta temperatura ambiente no momento da avaliação associada com a alta Qfolha incidente nas plantas da semeadura em 15/02 (Tabela 2) podem ter desencadeado a elevada transpiração nas plantas dessa época, além das plantas terem apresentado uma das maiores médias de condutância estomática, favorecendo a entrada e saída de água das folhas.

A maior concentração interna de $\mathrm{CO}_{2}$ foi observada nas plantas das semeaduras em 01/02 e 01/03 (Tabela 3). Esse parâmetro quantifica a concentração de $\mathrm{CO}_{2}$ na câmara subestomática da folha, carbono que ainda não foi assimilado pela enzima Rubisco durante o processo de fotossíntese. Este fato está associado a menor taxa fotossintética observada nas plantas dessas duas épocas de semeadura.

Tabela 2. Temperatura foliar (Tfolha), radiação fotossinteticamente ativa incidente na superfície foliar (Qfolha) e condutância estomática $\left(\mathrm{g}_{\mathrm{s}}\right)$ de plantas de milho cultivadas em quatro épocas de semeadura. Dourados, MS, 2017.

\begin{tabular}{lccc}
\hline Épocas de Semeadura & Tfolha $\left({ }^{\circ} \mathrm{C}\right)$ & Qfolha $\left(\mu \mathrm{mol}\right.$ fótons $\left.\mathrm{m}^{-2} \mathrm{~s}^{-1}\right)$ & $\mathrm{g}_{\mathrm{s}}\left(\mathrm{mol} \mathrm{H}_{2} \mathrm{O} \mathrm{m}^{-2} \mathrm{~s}^{-1}\right)$ \\
\hline $01 / 02 / 2015$ & $37,59 \mathrm{~b}$ & $1.063 \mathrm{c}$ & $0,241 \mathrm{~b}$ \\
$15 / 02 / 2015$ & $39,46 \mathrm{a}$ & $1.628 \mathrm{a}$ & $0,383 \mathrm{a}$ \\
$01 / 03 / 2015$ & $34,64 \mathrm{c}$ & $1.392 \mathrm{ab}$ & $0,261 \mathrm{~b}$ \\
$15 / 03 / 2015$ & $37,04 \mathrm{~b}$ & $1.226 \mathrm{bc}$ & $0,386 \mathrm{a}$
\end{tabular}

Médias seguidas das mesmas letras não diferem entre si segundo teste de Tukey, a 5\% de probabilidade.

Tabela 3. Concentração interna de $\mathrm{CO}_{2}$ (ci), transpiração (E) e eficiência do uso da água (EUA) de plantas de milho cultivadas em quatro épocas de semeadura. Dourados, MS, 2017.

\begin{tabular}{llll}
\hline Épocas de Semeadura & $\mathrm{ci}\left(\mu \mathrm{mol} \mathrm{CO}_{2} \mathrm{~m}^{-2} \mathrm{~s}^{-1}\right)$ & $\mathrm{E}\left(\mathrm{mmol} \mathrm{H}_{2} \mathrm{O} \mathrm{m}^{-2} \mathrm{~s}^{-1}\right)$ & $\mathrm{EUA}\left(\mathrm{mmol} \mathrm{H}_{2} \mathrm{O}\right)^{-1}$ \\
\hline $01 / 02 / 2015$ & $200,2 \mathrm{a}$ & $5,47 \mathrm{~b}$ & $2,94 \mathrm{c}$ \\
$15 / 02 / 2015$ & $160,2 \mathrm{~b}$ & $7,07 \mathrm{a}$ & $3,69 \mathrm{~b}$ \\
$01 / 03 / 2015$ & $196,8 \mathrm{a}$ & $4,86 \mathrm{~b}$ & $3,87 \mathrm{~b}$ \\
$15 / 03 / 2015$ & $163,0 \mathrm{~b}$ & $5,45 \mathrm{~b}$ & $4,89 \mathrm{a}$ \\
\hline
\end{tabular}

Médias seguidas das mesmas letras não diferem entre si segundo teste de Tukey, a 5\% de probabilidade. 
$\Delta \mathrm{C}\left(\mu \mathrm{mol} \mathrm{CO} \mathrm{mol}^{-1}\right)$
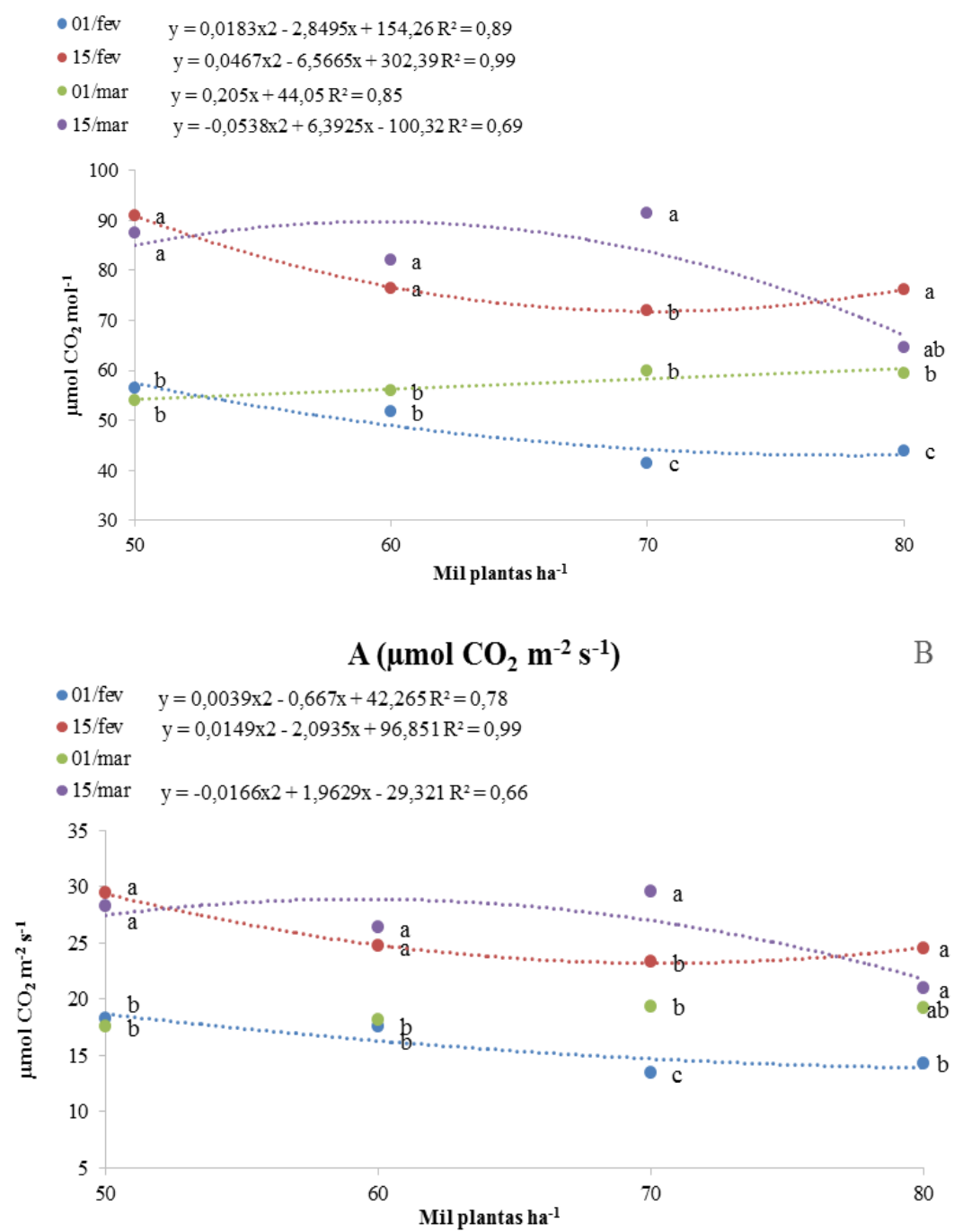

Figura 3. Consumo de carbono (A) e taxa fotossintética (B) de plantas de milho cultivadas em quatro épocas de semeadura e quatro populações de plantas. Pontos seguidos das mesmas letras não diferem entre si para épocas de semeadura, segundo teste de Tukey, a 5\% de probabilidade. Dourados, MS, 2017.

As plantas da semeadura em 15/03 apresentaram a maior média para eficiência do uso da água $(4,89 \mathrm{mmol}$ $\left.\mathrm{H}_{2} \mathrm{O}\right)^{-1}$ e, da semeadura em $01 / 02$, o menor valor $(2,94$ mmol $\left.\mathrm{CO}_{2} \mathrm{H}_{2} \mathrm{O}\right)^{-1}$ (Tabela 3). As plantas da semeadura em 15/03 apresentaram uma das maiores médias de taxa fotossintética e média intermediária para transpiração (Tabela 3), resultando em alta eficiência do uso da água. Entretanto, as plantas da semeadura em 01/02, mesmo com a média de transpiração semelhante à quarta época, apresentaram baixa taxa fotossintética, o que foi responsável pela menor eficiência do uso da água. Isso não quer dizer que as plantas da semeadura em 01/02 não foram eficientes em utilizar a água disponível, mas sim que, quando comparadas às outras épocas, a eficiência foi menor.

Magalhães et al. (2009) observaram maiores valores de eficiência do uso da água em plantas de milho no ambiente com deficiência hídrica, relacionando esse fato à economia de água durante as trocas gasosas por conta de menor condutância estomática.
$\mathrm{O}$ consumo de $\mathrm{CO}_{2}$ e a taxa fotossintética estão diretamente relacionados, apresentando assim comportamento similar. Dessa forma, como pode-se observar nas figuras $3 \mathrm{~A}$ e $3 \mathrm{~B}$, as plantas das semeaduras em 15/02 e 15/03 apresentaram maiores médias em ambas as variáveis. Nas semeaduras em 01/02 e 15/02 observou-se queda no consumo de $\mathrm{CO}_{2}$ e na taxa fotossintética ao elevar a população até 70 mil plantas $\mathrm{ha}^{-1}$, havendo aumento dos valores na maior população, porém, não sendo suficiente para alcançar as médias das plantas da população de 50 mil plantas $\mathrm{ha}^{-1}$. Na semeadura em 01/03, houve aumento linear do consumo de $\mathrm{CO}_{2}$ com o aumento da população e, para a taxa fotossintética, não houve diferença entre as médias das populações.

Os processos fotossintéticos estão relacionados à condutância estomática, pois as duas épocas de semeadura que apresentaram maior valor apresentaram também o maior consumo de $\mathrm{CO}_{2}$ e, consequentemente, maior taxa fotossintética (15/02 e 15/03). 
As maiores médias para eficiência de carboxilação da Rubisco foram observadas nas plantas das semeaduras em 15/02 e 15/03 (Figura 4A e 4B). Não houve ajuste para as populações de plantas nas semeaduras em 01/02 e 01/03. A eficiência da carboxilação é a razão entre a taxa fotossintética e a concentração interna de carbono. Sendo assim, altas taxas fotossintéticas combinadas com baixas concentrações internas de $\mathrm{CO}_{2}$ indicam elevada eficiência de carboxilação.

A baixa eficiência de carboxilação da Rubisco resulta em maiores concentrações internas de $\mathrm{CO}_{2}$ nas células das plantas, como ocorreu com as plantas das semeaduras em 01/02 e 01/03, ou seja, houve a absorção do $\mathrm{CO}_{2}$, porém, esse carbono não foi utilizado pela enzima Rubisco, resultando em menores consumos de $\mathrm{CO}_{2}$ e, consequentemente, em menores taxas fotossintéticas.

$\mathrm{Na}$ semeadura de 01/02 houve redução linear da eficiência fotoquímica da fotossíntese com o aumento da população. A semeadura de 15/02 apresentou resposta quadrática em relação ao aumento da população de plantas. Nas semeaduras em 01/03 e 15/03 não houve ajuste para as populações (Figura 4B).

Em relação aos parâmetros fotossintéticos que foram influenciados pela população de plantas, não se pode afirmar que existe decréscimo dos valores com o aumento da população em todas as épocas de semeadura. As semeaduras em 15/02 e 15/03 apresentaram comportamento quadrático na maioria das variáveis, com exceção da eficiência fotoquímica da fotossíntese, onde as médias da semeadura em 15/03 não seguiram a linha de tendência.

A análise de variância apresentou efeito isolado das épocas de semeadura e população de plantas para rendimento de massa seca de folha (RMSF), de colmo (RMSC) e total (RMST), grãos por espiga e massa de cem grãos (M100). As médias de diâmetro do colmo (DC) foram influenciadas apenas pela população de plantas, e, a produtividade, pela época de semeadura.

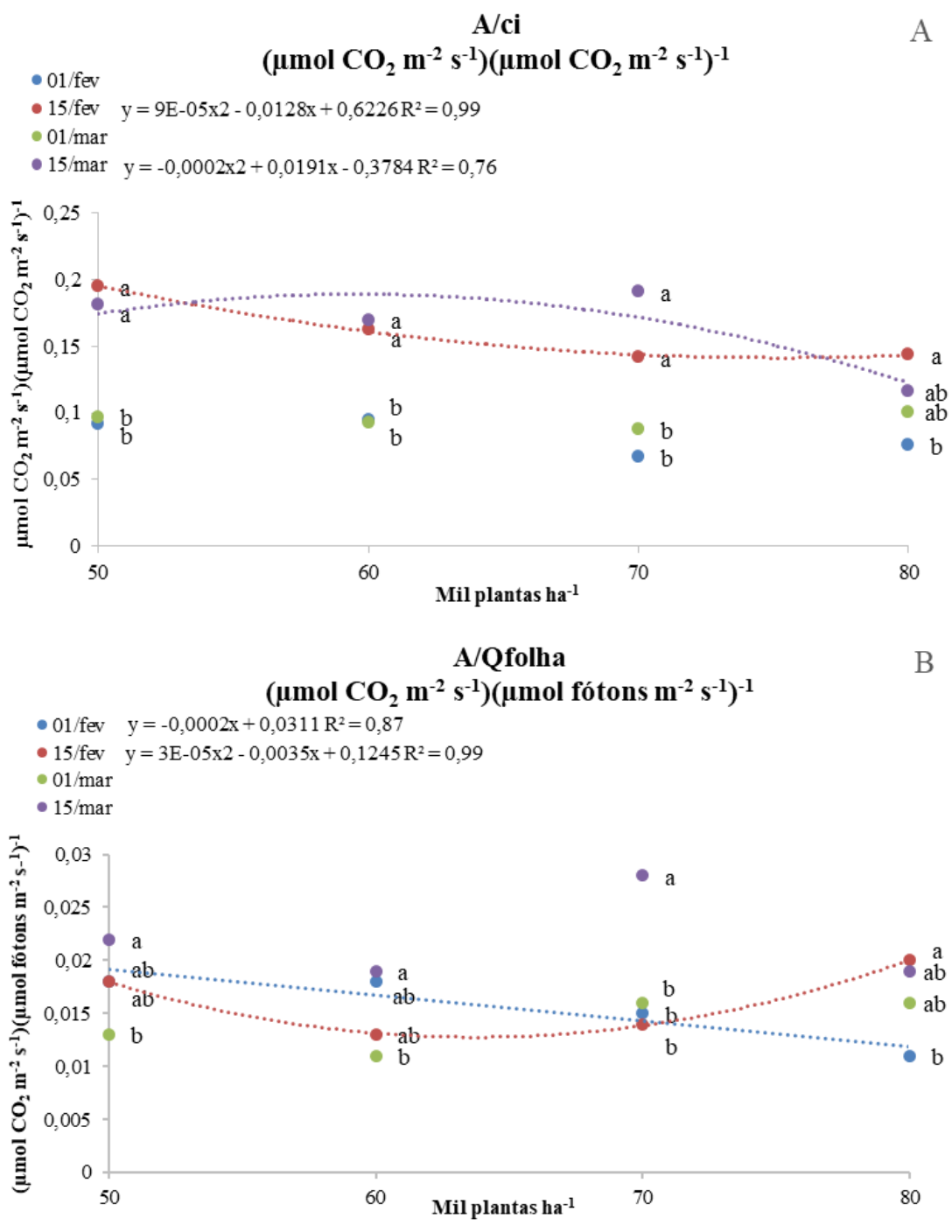

Figura 4. Eficiência de carboxilação da Rubisco (A) e eficiência fotoquímica da fotossíntese (B) de plantas de milho cultivadas em quatro épocas de semeadura e quatro populações de plantas. Pontos seguidos das mesmas letras não diferem entre si para épocas de semeadura, segundo teste de Tukey, a 5\% de probabilidade. Dourados, MS, 2017. 
Tabela 4. Rendimento de massa seca de colmo, folha e total de plantas de milho cultivadas em quatro épocas de semeadura. Dourados, MS, 2017.

\begin{tabular}{llll}
\hline Épocas de semeadura & RMSC $\left(\mathrm{kg} \mathrm{ha}^{-1}\right)$ & RMSF $\left(\mathrm{kg} \mathrm{ha}^{-1}\right)$ & $\left.\mathrm{RMST}^{-1} \mathrm{~kg} \mathrm{ha}^{-1}\right)$ \\
\hline $01 / 02 / 2015$ & $9.638 \mathrm{a}$ & $2.642 \mathrm{a}$ & $12.279 \mathrm{a}$ \\
$15 / 02 / 2015$ & $6.928 \mathrm{~b}$ & $2.479 \mathrm{a}$ & $9.407 \mathrm{~b}$ \\
$01 / 03 / 2015$ & $4.641 \mathrm{c}$ & $1.889 \mathrm{~b}$ & $6.530 \mathrm{c}$ \\
$15 / 03 / 2015$ & $6.943 \mathrm{~b}$ & $2.275 \mathrm{ab}$ & $9.218 \mathrm{~b}$ \\
\hline C.V.\% & 16,76 & 19,7 & 14,95 \\
\hline
\end{tabular}

Médias seguidas das mesmas letras não diferem entre si segundo teste de Tukey, a 5\% de probabilidade.

Tabela 5. Massa de cem grãos, número de grãos por espiga e produtividade de plantas de milho cultivadas em quatro épocas de semeadura. Dourados, MS, 2017.

\begin{tabular}{llll}
\hline Épocas de semeadura & M100 $(\mathrm{g})$ & Grãos Espiga $^{-1}$ & ${\text { Produtividade }\left(\mathrm{kg} \mathrm{ha}^{-1}\right)}^{-1}$ \\
\hline $01 / 02 / 2015$ & $30,04 \mathrm{~b}$ & $394,7 \mathrm{ab}$ & $7.648 \mathrm{a}$ \\
$15 / 02 / 2015$ & $31,35 \mathrm{a}$ & $414,1 \mathrm{a}$ & $8.137 \mathrm{a}$ \\
$01 / 03 / 2015$ & $32,08 \mathrm{a}$ & $409,6 \mathrm{a}$ & $7.564 \mathrm{a}$ \\
$15 / 03 / 2015$ & $27,95 \mathrm{c}$ & $375,2 \mathrm{~b}$ & $5.797 \mathrm{~b}$ \\
\hline C.V.\% & 3,56 & 8,8 & 11,3 \\
\hline
\end{tabular}

Médias seguidas das mesmas letras não diferem entre si segundo teste de Tukey, a 5\% de probabilidade.

As plantas da semeadura em 01/02 apresentaram maior rendimento de massa seca de colmo e estiveram entre as maiores médias de rendimento de massa seca de folhas; consequentemente, apresentaram a maior média para rendimento de massa seca total (Tabela 4). Maiores temperaturas e precipitação pluviométrica durante as primeiras cinco semanas da semeadura em 01/02 favoreceram a produção de massa seca do milho.

As plantas das semeaduras em 15/02 e 01/03 apresentaram as maiores médias para M100 e grãos por espiga. Em relação à produtividade de grãos, a única época que diferiu das demais foi a semeadura em 15/02, apresentando a menor média (Tabela 5). As plantas da semeadura em 01/03 apresentaram as maiores alturas, porém, menor acúmulo de massa seca se comparadas com as outras épocas de semeadura. Entretanto, essa época apresentou uma das maiores médias para M100, grãos por espiga e produtividade de grãos.

As plantas da semeadura em 15/03 apresentaram a menor M100, número de grãos por espiga e produtividade. No estádio V12 começaram a se definir o número de óvulos (grãos em potencial) e o tamanho das espigas, embora o número de fileiras de grãos por espiga já estivesse definido em V5. Mas o número final de grãos por fileira só se completou uma semana antes do espigamento. Neste período de formação de óvulos e espigas, estresse por água ou nutrientes reduzem seriamente o número de grãos e o tamanho das espigas (Bergamaschi; Matzenauer, 2014), fato que foi observado na quarta época, havendo estresse hídrico no período de formação dos óvulos, aproximadamente no início de junho (Figura 1).

Houve decréscimo linear no diâmetro do colmo quando se elevou a população de plantas de milho (Figura 5A). Maiores populações condicionam plantas mais altas, pois é comum as plantas apresentarem crescimento rápido para evitar o sombreamento e se sobressair no dossel, sacrificando o desenvolvimento do diâmetro do colmo. Sangoi et al. (2002) e Brachtvogel et al. (2009) observaram diminuição do diâmetro do colmo e aumento da altura das plantas de milho cultivadas em elevadas populações. Penariol et al. (2003) citam que o maior crescimento em altura, provavelmente devido à competição por luz, pode não ter correspondido a um suprimento suficiente de água e nutrientes, proporcionando menores diâmetros de colmo com o aumento da densidade populacional.

$\mathrm{O}$ rendimento de massa seca de folha não seguiu a linha de tendência, que apresentou ajuste linear (Figura 5B). Diferente ocorreu com o rendimento de massa seca de colmo e total, apresentando ajuste quadrático, com queda na produção de massa seca quando a população ultrapassa 70 mil plantas ha ${ }^{-1}$ (Figura 6A e 6B). Segundo Gross et al. (2006), a densidade populacional interfere na massa individual das plantas, obtendo-se um decréscimo de matéria seca individual, principalmente do colmo, como resultado da competição intraespecífica pelos recursos do meio.

As maiores médias de grãos por espiga e massa de cem grãos foram observadas nas plantas da população de 50 mil plantas ha $^{-1}$, existindo decréscimo dos valores quando se eleva a população de plantas (Figura 7A e 7B). A baixa população proporcionou menor competição entre as plantas por água e nutrientes, além de pouco sombreamento, apresentando condições ideais para a formação das espigas, estabelecendo assim maior quantidade de grãos por espiga e maior acúmulo de massa nos grãos. Dourado Neto et al. (2003) observaram redução no tamanho das espigas e no índice de espigas por planta em populações elevadas, demonstrando que, nas menores populações, as plantas direcionam os fotoassimilados para formação de grãos, 
enquanto, nas maiores, os nutrientes são destinados para o crescimento, por estarem sob maior competição entre plantas.

Argenta et al. (2001) encontraram redução nos componentes de produção com o aumento da população de 50 mil plantas ha ${ }^{-1}$ para 65 mil plantas ha ${ }^{-1}$. Tais perdas foram compensadas por um maior número de plantas, e, consequentemente, por um maior número de espigas por área, pois a produtividade de grãos não foi afetada. O fato de maiores populações de plantas compensarem as perdas nos componentes de produção com maior número de espigas por área fez com que não houvesse diferença de produtividade entre as populações de plantas.
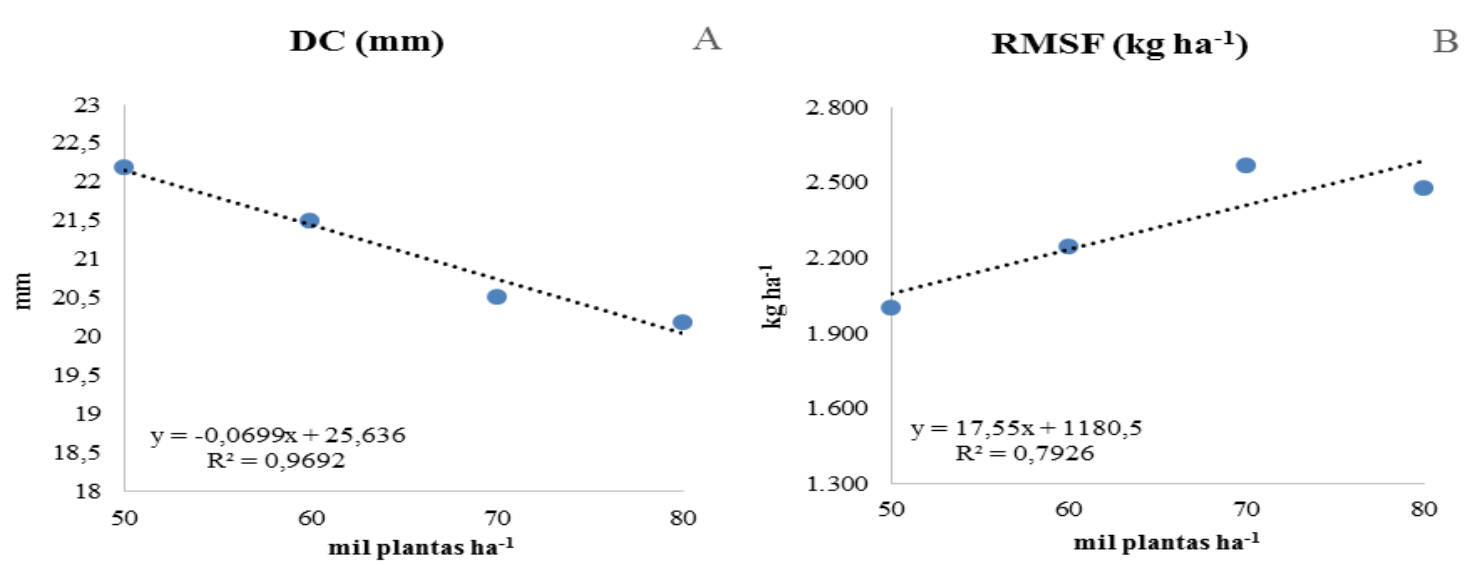

Figura 5. Diâmetro de colmo (A) e rendimento de massa seca de folhas (B) de plantas de milho cultivadas em quatro populações de plantas. Dourados, MS, 2017.
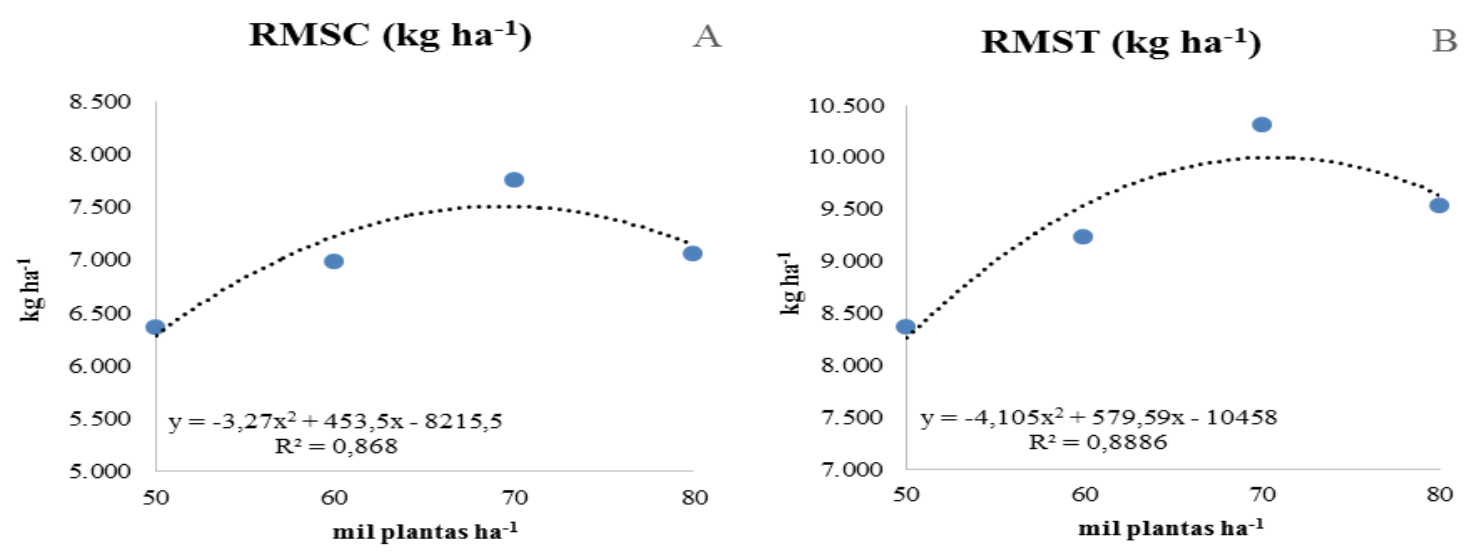

Figura 6. Rendimento de massa seca de colmo (A) e rendimento de massa seca total (B) de plantas de milho cultivadas em quatro populações de plantas. Dourados, MS, 2017.
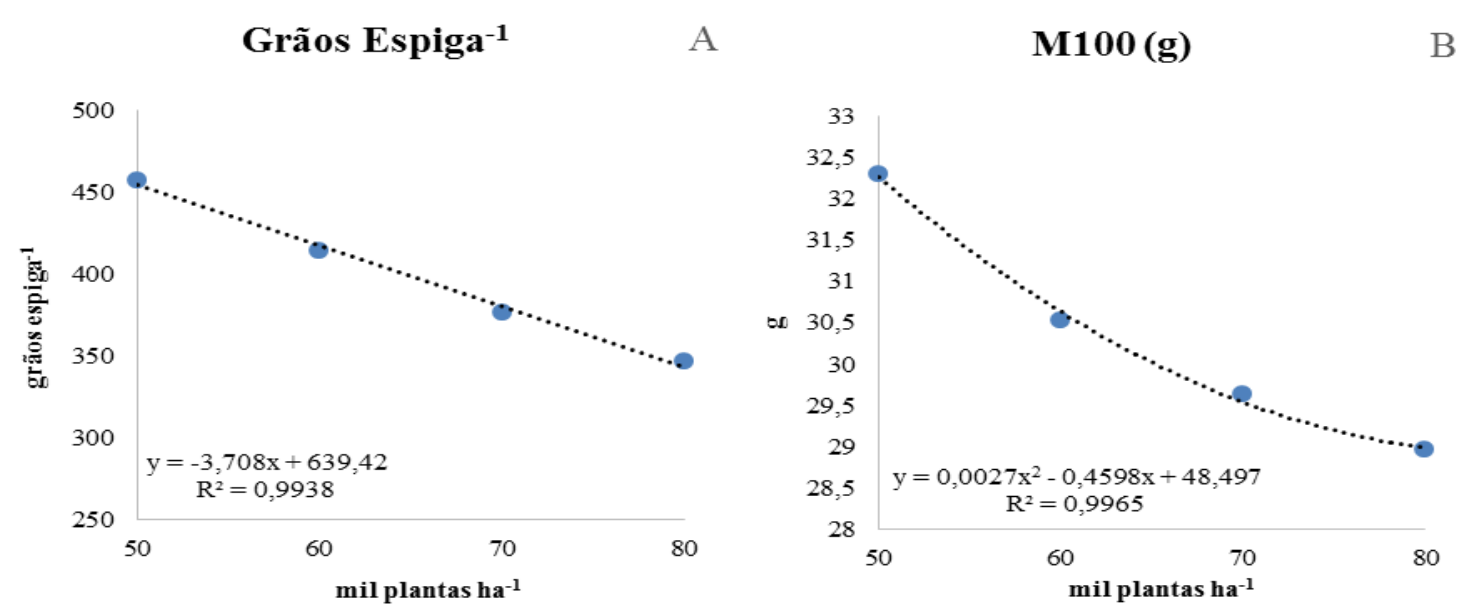

Figura 7. Número de grãos por espiga (A) e massa de cem grãos (B) de plantas de milho cultivadas em quatro populações de plantas. Dourados, MS, 2017. 
Em lavouras com alta população de plantas e sob boas condições de crescimento, as espigas adicionais resultarão em maior produtividade de grãos, por maximizar o número de grãos por área. Porém, essa compensação ocorre até que o maior número de espigas por área não seja mais suficiente para compensar a redução do número e da massa dos grãos (Dourado Neto et al., 2003).

$\mathrm{O}$ fato de não existir diferença de produtividade entre as populações de plantas quando existe boa distribuição pluviométrica durante o período de condução da cultura é indicativo de que não é necessário o uso de elevadas populações para garantir satisfatória produtividade, já que as populações de 50 e 60 mil plantas ha ${ }^{-1}$ são tão produtivas quanto às demais, com menor gasto de sementes.

\section{Conclusões}

As semeaduras realizadas na segunda quinzena de fevereiro e março favoreceram os processos fotossintéticos das plantas de milho.

A maior produtividade ocorreu com a semeadura na segunda quinzena de fevereiro.

Menores populações de milho foram suficientes para garantir satisfatória produtividade do milho safrinha.

\section{Referências Bibliográficas}

Argenta, G.; Silva, P. R. F.; Bortolini, C. G.; Forsthofer, E. L.; Manjabosco, E. A.; Beheregaray Neto, V., 2001. Resposta de híbridos simples à redução do espaçamento entrelinhas. Pesquisa Agropecuária Brasileira, 36, 1, 71-78.

Bergamaschi, H.; Matzenauer, R., 2014. O milho e o clima. Emater-Ascar, Porto Alegre, 84 p.

Brachtvogel, E. L.; Pereira, F. R. S.; Cruz, S. C. S.; Bicudo, S. J., 2009. Densidades populacionais de milho em arranjos espaciais convencional e equidistante entre plantas. Ciência Rural, 39, 8, 2334-2339.

Costa, G. F.; Marenco, R. A., 2007. Fotossíntese, condutância estomática e potencial hídrico foliar em árvores jovens de andiroba (Carapa guianensis). Acta Amazônica, 37, 2, 229234.

Cruz, C. D., 2004. Programa Genes - Versão Windows: aplicativo computacional em genética e estatística. Versão 2004.2.1. UFV, Viçosa.
Dourado Neto, D.; Palhares, M.; Vieira, P. A.; Manfron, P. A.; Medeiros, S. L. P.; Romano, M. R., 2003. Efeito da população de plantas e do espaçamento sobre a produtividade de milho. Revista Brasileira de Milho e Sorgo, 2, 3, 63-77.

Embrapa. Empresa Brasileira de Pesquisa Agropecuária, 2016. Guia Clima. Agropecuária Oeste, Dourados. http://clima.cpao.embrapa.br/ (acessado 17 de dezembro de 2016).

Ferreira, C. A. G.; Davide, A. C.; Carvalho, L. R., 1999. Relações hídricas em mudas de Eucalyptus citriodora Hook., em tubetes, aclimatadas por tratamentos hídricos. Cerne, 5, 2, 95-104.

Gross, M. R.; Pinho, R. G.; Brito, A. H., 2006. Adubação nitrogenada, densidade de semeadura e espaçamento entre fileiras na cultura do milho em sistema de plantio direto. Ciência e Agrotecnologia, 30, 3, 387-393.

Kappes, C.; Andrade, J. A. C.; Arf, O.; Oliveira, A. C.; Arf, M. V.; Ferreira, J. P., 2011. Desempenho de híbridos de milho em diferentes arranjos espaciais de plantas. Bragantia, 70, 2, 334-343.

Magalhães, P. C.; Souza, T. C.; Emílio, P.; Albuquerque, P.; Karam, D.; Magalhães, M. M.; Cantão, F. R. O., 2009. Caracterização ecofisiológica de linhagens de milho submetidas a baixa disponibilidade hídrica durante $o$ florescimento. Revista Brasileira de Milho e Sorgo, 8, 3, 223 232.

Oliveira, A. D.; Fernandes, E. J.; Rodrigues, T. D. J., 2005. Condutância estomática como indicador de estresse hídrico em feijão. Engenharia Agrícola, 25, 1, 86-95.

Penariol, F. G.; Fornasieri Filho, D.; Coicev, L.; Bordin, B.; Farinelli, R., 2003. Comportamento de cultivares de milho semeadas em diferentes espaçamentos entre linhas e densidades populacionais, na safrinha. Revista Brasileira de Milho e Sorgo, 2, 2, 52-60.

Sangoi, L.; Almeida, M. L.; Gracietti, M. A.; Bianchet, P.; Horn, D., 2002 Sustentabilidade do colmo em híbridos de milho de diferentes épocas de cultivo em função da densidade de plantas. Revista de Ciências Agroveterinárias, 1, 2, 1.

Sans, L. M. A.; Assad, E. D.; Guimarães, D. P.; Avellar, G., 2001. Zoneamento de riscos climáticos para a cultura de milho na Região Centro-Oeste do Brasil e para o estado de Minas Gerais. Revista Brasileira de Agrometeorologia, 9, 3, 527-535.

Santos, H. G.; Jacomine, P. K. T.; Anjos, L. H. C.; Oliveira, V. A.; Lumbreras, J. F.; Coelho, M. R.; Almeida, J. A.; Cunha, T. J. F.; Oliveira, J. B., 2013. Sistema brasileiro de classificação de solos, terceira ed. Embrapa Solos, Rio de Janeiro, 353p. 